Syntax Literate : Jurnal Ilmiah Indonesia p-ISSN: 2541-0849 e-ISSN : 2548-1398

Vol. 5 No. 3 Maret 2020

\title{
STEREOTYPE PEREMPUAN DI MEDIA FILM: OBYEK, CITRA DAN KOMODITI
}

\section{Dwi Kartikawati}

Fakultas Ilmu Sosial dan Ilmu Politik Universitas Nasional (UNAS) Jakarta

Email: dookartika@yahoo.com

\section{Abstract}

Women and films. Film as a media still places women full of stereotypes. This research focuses on the stereotypes of women in film media who studied was the film Love For Sale. This purpose of research is to knoww the signs and messages that stereotype women in the film. The research approach used is qualitative by the Roland Barthes Semiotics method which analyzes using two-graded meaning, that is the meaning of denotation, connotation and myth. The results showed that the signs of the female stereotype in the film Love For Sale were signs as objects that $i s$, the object of men's desire for satisfaction, then as an image, such as: image frames, image fusion, dish images and social images. And the third as a commodity that is realized through physical commodities, and behavior. Thus the stereotype reinforces the myth of women are subordinate parties which leads women as objects, images and commodities which strengthen the inauguration of men's hegemony on women.

Keywords: Stereotype, Woman, Media

\begin{abstract}
Abstrak
Perempuan dan film. Film sebagai media masih menempatkan posisi perempuan penuh dengan stereotype. Penelitian ini memfokuskan pada bagaimana stereotype perempuan di media Film yang dikaji adalah Film Love For Sale. Penelitian ini bertujuan untuk mengetahui tanda-tanda dan pesan pesan yang mestereotipekan perempuan dalam film tersebut. Pendekatan penelitian yang digunakan adalah kualitatif dengan metode Semiotika Roland Barthes, yang menganalisis menggunakan dua pemaknaan bertingkat, yaitu makna denotasi, makna konotasi dan mitos. Hasil penelitian menunjukkan bahwa tanda-tanda stereotype perempuan dalam Film Love For Sale ini adalah tanda sebagai obyek yaitu obyek hasrat kepuasan laki-laki, kemudian sebagai citra, antara lain: citra pigura, citra peraduan, citra pinggan dan citra pergaulan. Ketiga adalah sebagai komoditi yang diwujudkan melalui komoditi fisik, dan perilaku. Dengan demikian stereotype tersebut menguatkan mitos perempuan adalah pihak yang subordinate yang menggiring perempuan sebagai obyek, citra dan komoditi yang menguatkan pengukuhan hegemoni laki-laki atas perempuan.
\end{abstract}

Kata kunci: Stereotype, Perempuan, Media 


\section{Pendahuluan}

Ketika berbicara mengenai gender, maka gender merupakan sifat yang melekat pada laki-laki ataupun perempuan yang dikonstruksikan secara sosial dan budaya. Pada kasus ini seseorang trans gender khawatir akan terkena virus AIDS akan cenderung peka terhadap berbagai infeksi kuman apapun karena kekebalan tubuh yang melemah (Pratama, 2018). Perempuan masih distereotipkan sebagai perempuan yang indah yang membawa keindahan itu ke dalam sifat-sifat di sekitar keindahan tersebut, seperti perempuan harus tampil menawan, pintar mengurus rumah tangga, memasak, dapat menyenangkan pria, pantas diajak ke berbagai acara, cerdas dan sosok ideal lainnya. Stereotype ini menjadi ide dan citra sekaligus eksploitasi perempuan dan itu ditampilkan melalui media.

Stereotype distandarisasi pada konsepsi orang, terutama didasarkan pada individu yang termasuk dalam kategori (biasanya ras, bangsa, peran profesional, kelas sosial, atau gender) atau kepemilikan ciri-ciri karakteristik melambangkan salah satu kategori ini (Schweinitz, 2011). Karakteristik Stereotip dianggap: (1) relatif permanen sebagai alat mental individu (stabilitas); (2) didistribusikan secara intersubjektif di dalam formasi sosial tertentu, yang mereka anggap berfungsi membangun konsensus dan standardisasi (kesesuaian); oleh karena itu, (3) mereka tidak jarang mengandalkan pengalaman pribadi tetapi terutama dikomunikasikan secara sosial; selain itu, (4) mereka terbatas pada kombinasi sederhana dari beberapa karakteristik (reduksi) dan (5) disertai dengan perasaan kuat (pewarnaan afektif). Akhirnya, (6) berfungsi secara otomatis, stereotip dianggap secara substansial mengganggu proses persepsi dan penilaian, yang mempengaruhi dan bahkan menentukan (memiliki efek klise). Oleh karena itu umumnya terkait dengan membuat penilaian, dan (7) stereotip sering menganggap status penilaian yang tidak pantas (tidak memadai) terhadap sesuatu. Stereotype yang di makud dalam penelitian ini adalah stereotype perempuan di media. Stereotype muncul di media yang dimaksud, bisa di media iklan, media televisi, media film dan lain-lain.

Film umumnya dibangun dengan banyak tanda-tanda yang bekerja dengan sistem tanda dalam upaya menghasilkan efek, dalam film dapat terkandung fungsi informatif maupun edukatif, bahkan persuasif (Ardianto \& Komala, 2004). Isi pesan dari film tersebut dipercaya memiliki efek dan mempengaruhi audience-nya. Pada realita yang ada media film justru seringkali memunculkan jurang pemisah yang lebar antara berbagai hal yang ditampilkan dalam media dengan realita yang benar-benar dirasakan. Sayangnya gambaran perempuan di dunia perfilman baik nasional atau internasional lebih sering mendapatkan stereotype yang negatif. Perempuan dianggap hanya menjual kecantikan yang dimilikinya, keseksian yang terpancar dari dirinya dan tingkah laku yang di inginkan oleh para lelaki saat tampil di media perfilman tersebut. Kehadiran perempuan yang begitu lama dalam sejarah film ternyata belum bisa menghapus gambaran perempuan dalam stereotype yang negatif tersebut. Tampilan perempuan masih kurang berimbang antara menunjukkan perempuan dalam sosok 
yang pintar dan karier yang baik, atau menjadi pemimpin yang berhak mendapat penghormatan atas keberadaannya. Pandangan masyarakat mengenai perempuan sebagian besar juga terbentuk oleh apa yang selama ini digambarkan melalui film. Film menjadi alat untuk memenuhi kesenangan kaum lelaki. Film memang mampu membentuk konstruksi masyarakat temtang suatu hal, film juga merupakan rekaman realitas yang tumbuh dan berkembang dalam masyarakat dan kemudian memproyeksikannya ke atas layar (Sobur Alex, 2013). Secara definisi film adalah gambar bergerak. Secara esensial dan substansial film memiliki power yang akan berimplikasi terhadap komunikan masyarakat (Sutanto, 2017). Film secara umum dapat dibagi atas dua unsur pembentuk, yaitu unsur naratif (cerita) dan unsur sinematik. Dua unsur tersebut saling berinteraksi dan berkesinambungan satu sama lain untuk membentuk sebuah film (Pratista, 2008).

Unsur naratif adalah aspek-aspek ceritanya. Sementara unsur sinematik adalah aspek-aspek teknisnya, seperti kostum, make-up, atau tata cahaya. Kedua unsur tersebut harus dapat berjalan seimbang agar dapat menghasilkan film yang bagus dan menarik. Dalam film ada teknik pengambilan gambar, yang dilihat dari dimensi jarak kamera terhadap objek menurut (Sobur Alex, 2013) yaitu: Extreme Long Shot, Long Shot, Medium Long Shot, Medium Close-up, Close-up, Extreme Close Up. Dengan kekuatan film sebagai media komunikasi, maka film sangat berpotensi sebagai agen dalam pembentukan stereotip terhadap perempuan, sebagaimana yang dinyatakan dalam riset dari (Perdana, 2014) bahwa apa yang disosialisasikan oleh media akan membentuk stereotip tertentu. Stereotip merupakan bagian dari budaya yang diteruskan dan dipercayai oleh masyarakat tertentu, dalam hal ini film adalah medianya.

Tinjauan pada penelusuran penelitian-penelitian mengenai perempuan yang menunjukkan perempuan distereotipkan negatif di media, dapat kita lihat dari Penelitian (Anggraini, 2016). Yang Berjudul "Stereotip Perempuan Dalam Film Get Married". Dalam penelitian ini, film menjadi suatu pelajaran agar dapat memaknai kesetiaan dari persahabatan dan perilaku pada seorang perempuan tomboi. Menurut mitos perempuan di film ini menunjukkan sifat perempuan Betawi yang asli karena meskipun menyukai lelaki dia tetap menunggu lelaki itu yang datang bukan mengejar duluan. Kemudian penelitian dari (Ghassani \& Ghassani, 2010). Fakultas Ilmu Sosial dan Ilmu Politik Universitas Diponegoro Semarang. Dengan judul "Kekerasan Terhadap Perempuan (Analisis Semiotika Film Jamila dan Sang Presiden). Hasil penelitian (Ghassani \& Ghassani, 2010) menyimpulkan bahwa kekerasan terhadap perempuan dimanifestasikan dalam berbagai bentuk seperti kekerasan fisik, seksual, ekonomi, perampasan kemerdekaan sewenang-wenang, dan psikologis. Kemudian penelitian dari (Irawan, 2014), berjudul: "Representasi Perempuan dalam Industri Sinema. Hasil penelitian (Irawan, 2014) menggambarkan lamanya perempuan hadir dan berperan serta kuantitas jumlah mereka yang berimbang dengan laki-laki dalam industri sinema belum banyak memberikan kontribusi bagi peningkatan kualitas industri perfilman. 
Pada riset penulis ini dengan tujuan untuk mengetahui bagaimana stereotype perempuan digambarkan dalam media Film Love for Sale. Film ini di sutradarai Andibachtiar Yusuf, yang ditonton di awal pemutaran tahun 2018 mencapai 174 ribu penonton. Film Love for Sale pada Festival Film Bandung (FFB) 2018, meraih lima nominasi, yaitu untuk: Kategori Film Terpuji, Pemeran Utama Pria Terpuji (Gading Marten), Pemeran Pembantu Pria Terpuji (Verdi Solaiman), Penulis Skenario Terpuji (Andibachtiar Yusuf dan M. Irfan Ramli), dan Penata Artistik Terpuji (Adam Faozan Sudrajat).

Sekilas cerita film Love For Sale menggambarkan bagaimana tokoh Arini yang memiliki posisi tawar yang tinggi ketika 'bekerja' untuk Richard. Yang di maksud bekerja di sini, Arini bekerja sebagai teman kencan, teman untuk di ajak datang ke pernikahan, dan lain-lain, namun pada kenyataannya justru melalui film ini semakin menguatkan strereotype negatif pada pihak perempuan. Kontrak kerja Arini untuk menemani Richard sebanyak 45 hari.

Perempuan seolah-olah menjadi alat pendukung kesuksesan sebuah film. Gambaran seorang wanita dalam media massa hanya sering dijadikan sebagai bahan eksploitasi semata tanpa mengindahkan etika atau keberadaannya dalam masyarakat, hal tersebut menjadikan wanita dalam media massa hanya sebagai stereotip yang identik pada tubuh dan seksualitas semata. Keterlibatan perempuan dalam film di percaya mampu menguatkan isi pesan dalam film.

Dalam kacatama feminisme, yang memandang ketimpangan posisi perempuan dibandingkan posisi pria di masyarakat. Pria digambarkan sebagai sosok yang mendominasi (suferior) dan perempuan sebagai sosok yang didominasi (inferior). Maka riset ini akan membedah tanda-tanda stereotip perempuan melalui analisis semiotika Roland Barthes yang mengarah pada adanya stereotip yang muncul yaitu sebagai obyek, citra dan komoditas. Analisis semiotika Roland Barthes merupakan

Berdasarkan latar belakang yang telah diuraikan sebelumnya, maka Fokus dalam penelitian ini adalah "Bagaimana stereotipe perempuan yang ditampilkan dalam Film Love for Sale?. Adapun tujuan penelitian ini adalah untuk mendeskripsikan stereotpe dan mengetahui posisi perempuan dalam Film Love for Sale. Sedangkan manfaat penelitian secara akademis dapat memberikan sumbangan pemikiran dan memperkaya pembendaharaan kepustakaan bagi pengembangan ilmu pengetahuan khususnya yang berkaitan dengan kajian semiotika. Manfaat praktisnya adalah diharapkan ditujukan pada pihak produser film, masyarakat menjadi bahan pertimbangan dalam memilih dan menikmati film agar tidak terjebak memilih film yang tidak memiliki manfaat yang justru menguatkan stereotype negatif pada perempuan.

\section{Metode Penelitian}

Penelitian ini menggunakan pendekatan kualitatif. Dalam Studi ini menggunakan metode deskriptif analitik yang bertujuan untuk menggambarkan bentukbentuk stereotype perempuan dalam Film Love for Sale dengan metode analisis semiotika Roland Barthes. Hubungan antara petanda dan penanda tidak terbetuk secara 
alamiah, tetapi bersifat arbitrer yakni hubungan yang terbentuk berdasarkan konvensi. Maka dengan paradigma konstruktivisme peneliti menginterpretasikan stereotype perempuan dalam media Film Love For Sale yang merupakan hasi dari konstruksi realitas yang dibangun melalui simbol dan tanda yang konotatif dan denotatif. Penanda pasa dasarnya memberi peluang petandan sehingga bersifat subyektifis.

Secara etimologis, istilah semiotik berasal dari kata Yunani, Semeion yang berarti "tanda" (Wibowo, 2011). Tanda itu sendiri di definisikan sebagai sesuatu yang atas dasar konvensi sosial yang terbangun sebelumnya, dapat dianggap mewakili sesuatu yang lain. Secara terminologis, semiotik dapat di definisikan sebagai ilmu yang mempelajari sederetan luas objek-objek, peristiwa-peristiwa serta seluruh kebudayaan sebagai tanda.

Barthes ini terdapat istilah mitos. Mitos bukanlah tanda yang netral, melainkan menjadi penanda untuk memainkan pesan-pesan tertentu yang boleh jadi berbeda sama sekali dengan makna asalnya. Walaupun demikian, kandungan makna mitologis tidaklah dinilai sebagai sesuatu yang salah, namun dapat diartikan bahwa penandaan seringkali memproduksi mitos. Produksi mitos dalam teks membantu pembaca untuk menggambarkan situasi sosial budaya, mungkin juga politik yang ada disekelilingnya. Bagaimanapun mitos juga mempunyai dimensi tambahan yang disebut naturalisasi. Bagi Barthes, mitos bermain pada wilayah pertandaan tingkat kedua atau pada tingkat konotasi bahasa. Jika Sausure mengatakan bahwa makna adalah apa yang didenotasikan oleh tanda, Barthes menambah pengertian ini menjadi makna pada tingkat konotasi. Konotasi bagi Barthes justru mendenotasikan sesuatu hal yang ia nyatakan sebagai mitos, dan mitos ini mempunyai konotasi terhadap ideologi tertentu. Tanda konotatif tidak hanya memiliki makna tambahan, namun juga mengandung kedua bagian tanda denotatif yang melandasi keberadaannya.

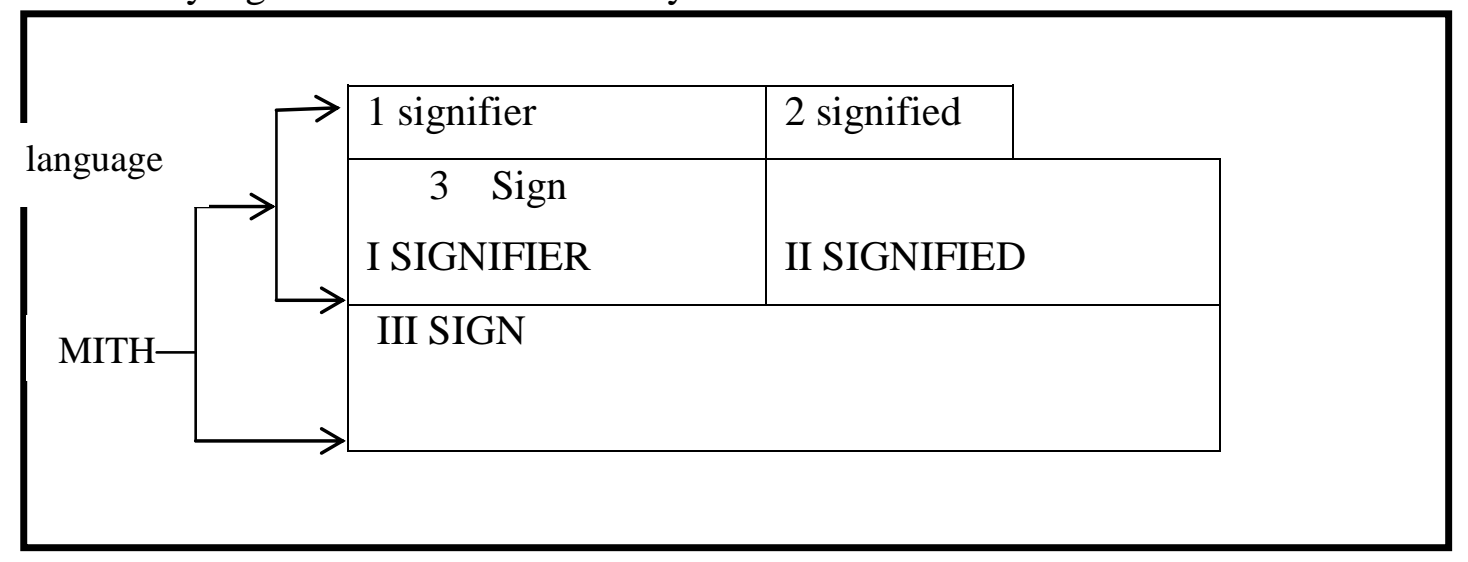

Gambar 1 Model Semiologi Roland Barthes

Pada tingkatan pertama (Language) Barthes memperkenalkan signifier (1) dan signified (2), yang gabungan keduanya menghasilkan sign (3) pada tingkatan pertama. Pada tingkatan kedua, sign (3) kembali menjadi SIGNIFIER (I) dan digabungkan dengan SIGNIFIED (II) dan menjadi SIGN (III). Sign yang ada ditingkatan ke dua inilah yang berupa $M Y T H$ (mitos) disebut juga sebagai metalanguage. 


\section{Hasil dan Pembahasan}

Pada hasil penelitian ini, Peneliti mendeskripsikan terlebih dahulu sinopsis singkat dari cerita film ini. Film Love for Sale merupakan film drama romantis Indonesia yang dirilis pada 15 Maret 2018 dan disutradarai oleh Andibachtiar Yusuf. Film ini dibintangi oleh Gading Marten dan Della Dartyan. Film ini merupakan film debut bagi Della Dartyan dan film pertama Gading Marten sebagai pemeran utama. Love For Sale juga hadir dalam bentuk novel yang ditulis oleh Endik Koeswoyo.

Gading Marten memenangkan Piala Citra untuk Aktor Terbaik untuk performanya di film ini, sementara Della Dartyan mendapatkan nominasi Aktris Terbaik dan filmnya sendiri mendapat nominasi Skenario Asli Terbaik.

\section{Sinopsis Film Love For Sale}

Richard Achmad dijuluki jomblo akut karena terlalu lama hidup sendiri. Suatu ketika teman-temannya memberi tantangan padanya: "Dua minggu lagi aku akan menikah, bawa pacarmu atau harga dirimu yang kami pertaruhkan." Maka segala cara diupayakan, sampai kemudian sebuah situs kencan mempertemukan dirinya dengan Arini Kusuma. Kesalahan administrasi membuat Richard terpaksa membiarkan Arini berlama bersamanya, setidaknya selama 45 hari sesuai masa kontrak. Perlahan benih asmara pun tumbuh hingga berhubungan intim. Richard terkesan dengan pemahaman Arini pada dirinya, pada hobinya bahkan pada selera makannya. Ia pun jatuh cinta pada Arini. Sesuatu yang tak pernah terjadi selama 20 tahun terakhir. Richard pun melamar Arini untuk selamanya bersamanya. Namun 45 hari berlalu dan Arini hilang tanpa pesan. Dan Richard pun sedih dan kecewa.

\section{Hasil analisis semiotika}

Pada hasil analisis, memfokuskan identifikasi tanda pada three order of signification, yaitu denotasi yaitu makna yang terlihat, kemudian konotasi sebagai perasaan dibalik makna yang terlihat, dan mitos sebagai justifikasi yang bersifat kekal. Adapun hasil temuan dan analisis sebagai berikut:

a) Sebagai Obyek

1) Scene menit ke 24.38: Penampilan Perempuan adalah Obyek hasrat kepuasan Laki-laki Tabel 1 Perempuan sebagai Obyek Hasrat Kepuasan laki-laki

\begin{tabular}{|c|c|c|}
\hline Visual & Verbal & $\begin{array}{c}\text { Teknik } \\
\text { Kamera }\end{array}$ \\
\hline & $\begin{array}{l}\text { Richard menerima telpon dari pihak } \\
\text { aplikasi dan menurut pihak alikasi } \\
\text { mengatakan: "menurut catatan kami. } \\
\text { Bapak sudah menginstall aplikasi } \\
9.01 \text {, nah kami ingin melanjutkan } \\
\text { apakah bapak mencari teman kencan, } \\
\text { atau sekedar menemani pernikahan. } \\
\text { Nah gimana?., kemudian Richard }\end{array}$ & Close Up \\
\hline
\end{tabular}




\begin{tabular}{ll}
\hline & menjawab: "yang menarik sih". Untuk \\
& tujuan kencan semalam aja sih.” \\
& Katanya. \\
\hline Denotasi & Richard menerima telpon sambil meilih-nilih foto- \\
& foto cantik dari aplikasi sambil minum kopi yang \\
& berasal dari aplikasi kencan. \\
\hline Konotasi & Richard membutuhkan perempuan sebagai obyek \\
& 'kencan' atau menemani dia yang sudah lama \\
& sendiri (menduda) \\
\hline Mitos & Stereotype perempuan menjadi obyek hasrat \\
& kepuasan bagi laki-laki menguatkan mitos \\
& "perempuan yang menarik yang melayani pria \\
& adalah yang cantik, muda, menarik. Konstruksi \\
& sosial tentang seksualitas tersebut menyebabkan \\
perempuan adalah subordinate.
\end{tabular}

Sebagai Obyek

Scene menit ke 55.15: Tubuh perempuan adalah obyek seksual pria Tabel 2 Perempuan sebagai Obyek Seksual

\begin{tabular}{llc}
\hline & \multicolumn{1}{c}{ Verbal } & $\begin{array}{c}\text { Teknik } \\
\text { kamera }\end{array}$ \\
\hline & Suara musik saja & $\begin{array}{c}\text { Medium } \\
\text { Close Up }\end{array}$ \\
& & \\
\hline Denotasi & $\begin{array}{l}\text { Richard dan Arini sedang ditempat tidur berciuman, } \\
\text { tanpa busana }\end{array}$ \\
\hline Konotasi & $\begin{array}{l}\text { Arini dan Richard berhubungan intim layaknya suami } \\
\text { istri }\end{array}$ \\
\hline Mitos & $\begin{array}{l}\text { Perempuan menjadi obyek seksual laki-laki---ideologi } \\
\text { patriarki }\end{array}$ \\
\hline
\end{tabular}

b) Sebagai Citra

a. Scene menit ke 54.16: Citra Pigura adalah citra perempuan sebagai sosok yang sempurna dengan bentuk tubuh ideal, perempuan digambarkan sebagai makhluk yang harus memikat, sebagai makhluk yang cantik dan harus selalu menjaga kecantikannya. 
Tabel 3: Perempuan sebagai Citra Pigura

\begin{tabular}{|c|c|c|}
\hline Visual & Verbal & $\begin{array}{c}\text { Teknik } \\
\text { kamera }\end{array}$ \\
\hline & $\begin{array}{l}\text { Richard mengajak Arini ke pernikahan } \\
\text { temennya yang bernama Rudi. Arini secara } \\
\text { fisik cantik, tinggi, langsing. Kata Richard } \\
\text { ke teman-temannya: "Kan aku udah bilang } \\
\text { aku punya pacar". } \\
\text { Richard sambil memperlihatkan Arini ke } \\
\text { teman-teman dengan merangkul mesra. . }\end{array}$ & $\begin{array}{l}\text { Medium } \\
\text { Long } \\
\text { Shot }\end{array}$ \\
\hline Denotasi & \multicolumn{2}{|c|}{$\begin{array}{l}\text { Richard memeluk Arini yang tubuhnya langsing dan } \\
\text { cantik untuk dikenalkan ke teman temannya }\end{array}$} \\
\hline Konotasi & \multicolumn{2}{|c|}{$\begin{array}{l}\text { Arini sebagai 'pacar' yang memikat dari tampilan } \\
\text { fisiknya }\end{array}$} \\
\hline Mitos & \multicolumn{2}{|c|}{$\begin{array}{l}\text { Perempuan bercitra pigura bagi laki-laki perempuan } \\
\text { untuk tampil dengan memikat, karenanya tuntutan } \\
\text { cantik, muda, langsing dan wajah yang menarik }\end{array}$} \\
\hline
\end{tabular}

b. Scene menit ke 47.34: Citra pilar yaitu citra di mana perempuan memiliki tanggungjawab lebih besar dalam urusan domestik, pengurus utama keluarga.

Tabel 4: Perempuan sebagai Citra Pilar

\begin{tabular}{|l|l|l|}
\hline \multicolumn{1}{|c|}{ Visual } & \multicolumn{1}{|c|}{ Verbal } & \multicolumn{1}{c|}{$\begin{array}{c}\text { Teknik } \\
\text { kamera }\end{array}$} \\
\hline Konotasi & $\begin{array}{l}\text { Arini: “Hei udah pulang?', Mau teh?" } \\
\text { Richard: (mengangguk), tadi seharian } \\
\text { ngapain aja } \\
\text { Arini: Aku Nonton teve } \\
\text { Richard: Sabtu ini mau nonton bareng ga } \\
\text { sama anak- anak?', Biar kamu ga disini } \\
\text { sini aja. } \\
\text { Arini: Oke, Kalau ga repot }\end{array}$ & Shot \\
\hline Denotasi & $\begin{array}{l}\text { Arini selalu siap menyiapkan makanan, mengurusi } \\
\text { dapur dan menawarkan minuman teh ke Richard Arini } \\
\text { melakukan pekerjaan domestik di rumah }\end{array}$ \\
\hline $\begin{array}{l}\text { Citra bahwa seorang perempuan yang penuh kasih } \\
\text { sayang serta perhatian bagi si laki-laki, memperhatikan } \\
\text { kebutuhan pasangannya }\end{array}$ \\
\hline
\end{tabular}




\begin{tabular}{|l|l|}
\hline Mitos & $\begin{array}{l}\text { Perempuan bercitra pilar, siap selalu melayani laki-laki } \\
\text { dalam urusan domestik. }\end{array}$ \\
\hline
\end{tabular}

c. Scene menit ke 55.16. Citra peraduan: perempuan sebagai objek seksual. Citra dimana perempuan ditonjolkan dalam aspek seks dan seksualitasnya. Yang menganggap perempuan adalah objek pemuas lelaki.

Tabel 5: Perempuan sebagai Citra Peraduan

\begin{tabular}{|l|l|c|}
\hline \multicolumn{1}{|c|}{ Visual } & \multicolumn{1}{|c|}{ Verbal } & $\begin{array}{c}\text { Teknik } \\
\text { kamera }\end{array}$ \\
\hline & $\begin{array}{l}\text { Richard dan Arini sama sama telanjang } \\
\text { tanpa suara sedang memadu kasih } \\
\text { sebagaimana suami istri }\end{array}$ & $\begin{array}{l}\text { Medium } \\
\text { Close Up }\end{array}$ \\
\hline Denotasi & $\begin{array}{l}\text { Richard dan Arini berpelukan dengan punggung } \\
\text { belakang Arini kelihatan tidak menggunakan pakaian }\end{array}$ \\
\hline Konotasi & Richard dan Arini berhubungan intim di tempat tidur \\
\hline Mitos & Perempuan adalah obyek seksual di tempat tidur \\
\hline
\end{tabular}

d. Scene menit ke: 44.17 : citra pinggan: perempuan sebagai sosok yang identik dengan dunia dapur.

Tabel 6: Perempuan sebagai Citra Pinggan

\begin{tabular}{|c|c|c|}
\hline Visual & Verbal & $\begin{array}{r}\text { Teknik } \\
\text { kamera }\end{array}$ \\
\hline & $\begin{array}{l}\text { Karakter Arini, meski hadir untuk bikin } \\
\text { Richard jatuh hati dengan kemampuannya } \\
\text { 'melayani' makan siang. } \\
\text { Arini: Ayuk makan, enak kan" } \\
\text { Richard: enak, sambil memandang Arini. }\end{array}$ & $\begin{array}{l}\text { Medium } \\
\text { Long } \\
\text { Shot }\end{array}$ \\
\hline Denotasi & \multicolumn{2}{|c|}{$\begin{array}{l}\text { Arini menyiapkan makan siang Richard di rumah pas } \\
\text { pulang kantor }\end{array}$} \\
\hline Konotasi & \multicolumn{2}{|c|}{$\begin{array}{l}\text { Arini adalah perempuan yang mampu melayani laki- } \\
\text { laki (Richard) dalam kebutuhan dasar makanan bergisi. }\end{array}$} \\
\hline Mitos & \multicolumn{2}{|c|}{$\begin{array}{l}\text { Perempuan adalah lekat dengan pekerjaan domestik- } \\
\text { ideologi patriarki }\end{array}$} \\
\hline
\end{tabular}

e. Scene menit ke 34.17 adalah citra pergaulan: perempuan digambarkan sebagai makhluk yang dipenuhi kekhawatiran tidak memikat atau tampil menawan. 
Tabel 7: Perempuan sebagai Citra Pergaulan

\begin{tabular}{|l|l|c|}
\hline \multicolumn{1}{|c|}{ Visual } & \multicolumn{1}{c|}{ Verbal } & \multicolumn{1}{c|}{$\begin{array}{c}\text { Teknik } \\
\text { kamera }\end{array}$} \\
\hline Denotasi & $\begin{array}{l}\text { Arini: "Aku arini, oh ini temen temen mas } \\
\text { Richard ya?." } \\
\text { Teman-temannya: saling salam dan } \\
\text { senyum }\end{array}$ & $\begin{array}{l}\text { Medium } \\
\text { close up }\end{array}$ \\
\hline Konotasi & $\begin{array}{l}\text { Richard dan Arini berdua menghadiri pesta pernikahan } \\
\text { kawannya Richard. }\end{array}$ \\
\hline Mitos & $\begin{array}{l}\text { Arini sebagai sosok pacar yang bisa bergaul di mana } \\
\text { saja. }\end{array}$ \\
\hline $\begin{array}{l}\text { Perempuan secara ideologis harus mampu berada } \\
\text { dalam situasi yang diinginkan laki-laki termasuk } \\
\text { dalam pergaulan. }\end{array}$ \\
\hline
\end{tabular}

\section{c) Sebagai komoditi}

Tubuh perempuan melalui pesona kecantikan fisik tubuhnya 'dimanfaatkan' dalam berbagai aktivitas ekonomi.

a. Scene menit ke: $\mathbf{5 4 . 0 8}$ komoditi fisik

Tabel 8. Perempuan sebagai komoditi fisik

\begin{tabular}{|l|l|c|}
\hline \multicolumn{1}{|c|}{ Visual } & \multicolumn{1}{|c|}{ Verbal } & $\begin{array}{c}\text { Teknik } \\
\text { kamera }\end{array}$ \\
\hline & $\begin{array}{l}\text { Richard dan Arini hanya saling pandang } \\
\text { dan membuka pakaian masing-masing } \\
\text { untuk berhubungan badan }\end{array}$ & $\begin{array}{l}\text { Medium } \\
\text { close up }\end{array}$ \\
\hline Denotasi & $\begin{array}{l}\text { Arini berhadapan dengan Richard dalam kondisi tanpa } \\
\text { busana dan memperlihatkan fisiknya }\end{array}$ \\
\hline Konotasi & $\begin{array}{l}\text { Tubuh Arini menjadi obyek sasaran laki laki yaitu } \\
\text { Richard untuk berhubungan badan }\end{array}$ \\
\hline Mitos & \begin{tabular}{l} 
Tubuh perempuan adalah komoditi milik laki-laki \\
\hline
\end{tabular} &
\end{tabular}


b. Scene menit ke 35.29: komoditi perilaku

Tabel 9. Perempuan sebagai komoditi perilaku

\begin{tabular}{|c|c|c|}
\hline Visual & Verbal & $\begin{array}{r}\text { Teknik } \\
\text { kamera }\end{array}$ \\
\hline & $\begin{array}{l}\text { Richard memberikan uang ke Arini untuk } \\
\text { membayar jasa telah menemaninya. } \\
\text { Arini: "Maksudnya apa ya mas?, } \\
\text { Richard: " buat ongkos taksi, sisanya buat } \\
\text { kamu } \\
\text { Arini: : Mas ikatan kerja kita } 45 \text { hari, kalau } \\
\text { sekarang udah saya bilang apa ke kantor } \\
\text { Richard: Bilang aja kerjaan udah beres } \\
\text { Arini: Ada teman saya, dia dikontrak } \\
\text { selama } 15 \text { hari. Pada hari ke tujuh dia } \\
\text { dipulangkan, dia dipecat oleh kantor. } \\
\text { Bapak saya itu sakit sakitan mas, matanya } \\
\text { udah ga bagus. Keluarga sangat } \\
\text { mengandalkan saya untuk cari uang. } \\
\text { Kemudian Arini menangis. Akhirnya } \\
\text { Richard membawa ke rumahnya untuk } \\
\text { tinggal bersama selama } 45 \text { hari sesuai } \\
\text { kontrak kencan diawal. }\end{array}$ & Close up \\
\hline Denotasi & \multicolumn{2}{|c|}{$\begin{array}{l}\text { Arini berhadapan dengan Richard di mobil yang } \\
\text { menunjukkan gerak gerik perempuan yang lemah } \\
\text { lembut menarik hati Richard. }\end{array}$} \\
\hline Konotasi & \multicolumn{2}{|c|}{$\begin{array}{l}\text { Tubuh Arini menjadi obyek ketertarikan laki laki } \\
\text { melalui perlaku lemah lembut, keibuan, dan konsisten } \\
\text { melayani, dan lain lain }\end{array}$} \\
\hline Mitos & \multicolumn{2}{|c|}{$\begin{array}{l}\text { Perempuan adalah komoditi melalui gerak gerik } \\
\text { tubuhnya. Yang menjual jasa sebagai teman kencan di } \\
\text { aplikasi kencan. }\end{array}$} \\
\hline
\end{tabular}

Pada hasil temuan keseluruhan bahwa perempuan dijadikan objek utama dalam film ini, dan dilakukan dengan dengan eksploitasi dalam bentuk tubuh, wajah, rambut, suara dan seluruh tubuhnya. Bentuk eksploitasi tersebut dapat kita lihat dalam media film yang kerap kali perempuan dijadikan objek seksual, dimana tubuh perempuan dijadikan alat untuk memancing daya tarik. Serta mengeksplorasi sensualitas tubuh perempuan guna memanfaatkannya sebagai alat saja.

Pada hasil temuan citra, inilah citra perempuan yang berhasil dibentuk dalam media massa: a) Citra Pigura: perempuan sebagai sosok yang sempurna dengan bentuk tubuh yang ideal. b) Citra Pilar: perempuan sebagai penyangga keutuhan dan penata rumah tangga. c) Citra Peraduan: perempuan sebagai objek seksual. d) Citra Pinggan: 
perempuan sebagai sosok yang identik dengan dunia dapur. e) Citra pergaulan. Karena itu, gambaran perempuan dalam media massa merupakan cermin realitas yang ada dalam masyarakatnya. Bias jender yang terjadi dalam reproduksi citra perempuan di media film.

Perempuan menjadi komoditi di media film, telah menjadi sarana legimitasi daya tarik terhadap aktualisasi nilai film melalui fisik tubuh dan perilaku. Faktor utama dalam menentukan "nilai jual", karena tubuh diyakini sebagai sarana untuk menikmati kesenangan, kenikmatan dan ekspresi diri. Film merupakan salah satu media komunikasi massa, di satu sisi merefleksikan kehidupan masyarakat beserta nilai, norma, dan gaya hidup yang berlaku di masyarakat. Namun, di sisi lain, film juga memiliki kuasa untuk menetapkan nilai-nilai budaya yang penting dan perlu diikuti oleh masyarakat menurut prespektif pembuatnya. Realitas sosial yang dihadirkan dalam film ini tidak terlepas dari ideology dan kepentingan pembuatnya. Peran media dalam melalui film ini mengkuhkan hegemoni laki-laki atas perempunan. Bagi para audience media terutama perempuan, tulisan ini diharapkan mampu memberikan wacana dan kesadaran yang lebih baik terkait dengan posisi dan perannya sebagai perempuan, sebagaimana yang telah diperjuangkan melalui emansipasi perempuan, yaitu persamaan hak dan posisi dengan pria. Dan juga menumbuhkan kesadaran, bahwa perempuan sekarang juga harus jeli dan kritis dalam melihat tampilan atau isi yang dimuat di media, apabila hana sebagai obyek eksploitasi dari kaum laki-laki. Perempuan dalam media digambarkan penuh stereotype mengakibatkan perempuan menjadi anggota masyarakat yang terhegemoni. Perempuan terhegemoni dalam dunia laki-laki, dalam dunia patriarkis Perempuan dengan bentuk fisiknya, tubuhnya dipandang tak lebih hanya sebagai barang bernilai komersil.

\section{Kesimpulan}

Hasil penelitian ini menunjukkan bahwa dalam Film Love For Sale menggambarkan perempuan lekat dengan stereotype di media film yaitu sebagai obyek, citra dan komoditi. Sebagai obyek dalam bentuk eksploitasi dalam bentuk tubuh sebagai objek kepuasan dan obyek seksual laki-laki. Sebagai citra muncul dalam bentuk Citra Pigura, Citra Pilar, Citra Peraduan, Citra Pinggan dan Citra pergaulan. Bias jender yang terjadi dalam reproduksi citra perempuan di media Film Love for Sale ini. Kemudian perempuan menjadi komoditi di media film, melalui komoditi fisik tubuh dan perilaku perempuan. Hasil penelitian ini diharapkan mampu memberikan wacana dan kesadaran yang lebih baik terkait dengan posisi dan perannya sebagai perempuan, dan mengkritisi dalam melihat tampilan/ isi yang dimuat di media, terutama dalam hal ini media memandang perempuan semata-mata sebagai obyek eksploitasi dari kaum laki-laki. Perempuan dalam media digambarkan penuh stereotype mengakibatkan perempuan menjadi anggota masyarakat yang terhegemoni. Perempuan terhegemoni dalam dunia laki-laki, dalam dunia patriarki. Dengan demikian stereotype tersebut menguatkan mitos perempuan adalah pihak yang subordinate yang menggiring perempuan sebagai obyek, citra dan komoditi yang menguatkan pengukuhan hegemoni laki-laki atas perempuan. 
Stereotype Perempuan Di Media Film 
Dwi Kartikawati

\section{BIBLIOGRAFI}

Anggraini, D. (2016). Stereotip Perempuan Dalam Film Get Married Analisis Semiotika Roland Bhartes. EJournal Ilmu Administrasi Bisnis.

Ardianto, E., \& Komala, L. (2004). Komunikasi massa: suatu pengantar. Simbiosa Rekatama Media.

Ghassani, H., \& Ghassani, H. (2010). Kekerasan Terhadap Perempuan: Analisis Semiotika Film Jamila dan Sang Presiden. Diponegoro University.

Irawan, R. E. (2014). Representasi perempuan dalam industri sinema. Humaniora, 5(1), $1-8$.

Perdana, D. D. (2014). Stereotip Gender Dalam Film Anna Karenina. Interaksi: Jurnal Ilmu Komunikasi, 3(2), 123-130.

Pratama, F. (2018). Implementasi Kebijakan Dalam Penanggulangan Virus Hiv Dan Aids Di Kabupaten Kuningan. Syntax Literate; Jurnal Ilmiah Indonesia, 3(2), 2634.

Pratista, H. (2008). Memahami film. Homerian Pustaka.

Schweinitz, J. (2011). Film and stereotype: A challenge for cinema and theory. Columbia University Press.

Sobur Alex. (2013). Semiotika Komunikasi . Remaja Rosdakarya.

Sutanto, O. (2017). Representasi Feminisme Dalam Film "Spy.” Jurnal E-Komunikasi, $5(1)$.

Wibowo, I. S. W. (2011). Semiotika Komunikasi: Aplikasi praktis bagi penelitian dan skripsi komunikasi. Jakarta: Mitra Wacana Media. 